\title{
PAISAGENS NO NÚCLEO DE DESERTIFICAÇÃO DOS INHAMUNS E SEU ENTORNO, CEARÁ, BRASIL
}

\author{
Pedro Ítalo Carvalho Aderaldo \\ Universidade Estadual de Campinas - Unicamp \\ (1) https://orcid.org/0000-0002-6598-8166 \\ pedroitaloo@hotmail.com
}

\begin{abstract}
Paisagens no núcleo de desertificação dos Inhamuns e seu entorno, Ceará, Brasil (Resumo)
\end{abstract}

\begin{abstract}
A área de estudo localizada no estado do Ceará, Brasil, configura-se por paisagens que abrangem rica biodiversidade e o bioma Caatinga, o único no mundo. Nestas paisagens, também se evidenciam, marcas significativas de um passado com práticas predatórias e não sustentáveis, formando áreas com altos níveis de degradação ou desertificadas. Este artigo busca aprofundar o entendimento sobre as características físicas da área desertificada dos Inhumuns e o seu entorno, a partir de uma análise de cada compartimento do relevo identificado e representado em um mapa com escala de 1:250.000, elaborado com bases em atividades de campo e em imagens Shuttle Radar Topografy Mission (SRTM), com resolução espacial de 30 metros (Earth Explorer - U.S Geological Survey), através da utilização do software Arcgis. Nesse contexto, visa-se contribuir, com o embasamento para futuras pesquisas que envolvam planejamento do território e práticas sustentáveis.
\end{abstract}

Palavras-Chaves: Desertificação; Paisagens; Inhamuns; SRTM.

\section{Paisajes en el centro de desertificación de Inhamuns y sus alrededores, Ceará, Brasil (Resumen)}

El área de estudio, que está situado en el estado de Ceará, Brasil, se configura por paisajes que abarcan una rica diversidad y el bioma Caatinga, único en el mundo. En estos paisajes se observan, marcas significativas de un pasado con prácticas predatorias y no sostenibles, formando áreas con altos niveles de degradación o desertificación. Este articulo busca profundizar el entendimiento acerca de las características físicas del área desertificada de los Inhamuns y su entorno, partiendo del análisis de cada compartimiento de relieve identificado y representado en un mapa a escala 1:250.000, elaborado mediante observaciones de campo e imágenes Shuttle Radar Topografy Mission (SRTM), con resolución de 30 metros (Earth Explorer - U.S Geological Survey), a través del uso del software Arcgis. En este contexto, este estudio tiene como objetivo contribuir para futuras investigaciones sobre planeamiento territorial y prácticas sostenibles.

Palabras-clave: Desertificación; Paisaje; Inhamuns; SRTM. 


\section{Landscapes in the desertification core of Inhamuns and its surroundings, Ceará, Brazil (Abstract)}

The area of study, located in Ceará, Brazil state, arranges itself by landscapes that comprehend rich biodiversity and the caatinga biome, the only in the world. Present in these landscapes, there are significant evidences from a past of predatory and unsustainable practices, thus implying in areas with high degradation or desertification levels. This article seeks to deepen the understanding physical characteristics presented by the Inhamuns desertified area and its surroundings, based on analysis of each identified relief compartment, resulting in a map representation with scale of 1:250.000, produced based on field surveys and Shuttle Radar Topografy Mission (SRTM) imagery, with 30 meters spatial resolution (Earth Explorer - U.S Geological Survey), utilizing Arcgis software. In this context, the aim is to contribute with base knowledge for future research that involves territorial planning and sustainable practices.

Key words: Desertification; Landscapes; Inhamuns; SRTM.

\section{Introdução}

Entende-se que a desertificação, no século passado e atual, é um tema cativo nas pesquisas relacionadas ao meio ambiente, possivelmente justificado por a mesma estar dispersa em todos os continentes nas denominadas Áreas Suscetíveis à Desertificação (ASD's), tornando-a um problema que atinge de forma direta ou indireta todo o planeta.

A temática da desertificação foi introduzida no âmbito acadêmico brasileiro, com o trabalho intitulado "O Deserto Brasileiro". Nessa pioneira produção, indicam-se áreas com núcleos de desertificação, e as relacionam como pequenos desertos com patamares de irreversibilidade, marcados por degradação da cobertura vegetal e do solo ${ }^{1}$.

No mundo os problemas motivados pela degradação e desertificação, incidem sobre $33 \%$ da superfície da terra, onde vivem, aproximadamente, 2,6 bilhões de pessoas. Na América Latina essa problemática atinge, aproximadamente, 516 milhões de hectares, com perdas de bilhões de toneladas de terras cultiváveis por ano, e no Brasil configura-se com perdas econômicas anuais em torno de 800 milhões de dólares ${ }^{2}$.

As causas da desertificação, podem se assemelharem, entre os países em que a mesma é constatada. Na Espanha, de acordo com o "Programa de Acción Nacional Contra La Desertificación", publicado no ano de 2008, observa-se que a desertificação é causada pela intrínseca relação entre os fatores humanos, climáticos e geomorfológicos ${ }^{3}$.

No Brasil, as discussões sobre as causas da desertificação, mais evidenciadas ficam em torno dos fatores climáticos e antrópicos. Verifica-se que a desertificação pode ser entendida como

\footnotetext{
${ }^{1}$ Vasconcelos Sobrinho, 1974.

${ }^{2}$ Secretaria dos Recursos Hídricos - BRASIL, 2004

<https://www.mma.gov.br/estruturas/sedr_desertif/_arquivos/pan_brasil_portugues.pdf>.

Secretaria dos Recursos Hídricos - CEARÁ, 2010 <http://www.mpce.mp.br/wpcontent/uploads/2016/05/PROGRAMA-ESTADUAL-DE-COMBATE-A-

DESERTIFICA\%C3\%87\%C3\%830.pdf>.

${ }^{3}$ Ministerio de Medio Ambiente y Medio Rural y Marino - ESPAÑ, 2008

<https://www.mapa.gob.es/es/desarrollo-rural/temas/politica-forestal/pand_agosto_2008_tcm30-177181.pdf >.
} 
resultado das características naturais impostas pelos climas árido, semiárido e subúmidos, em associação com as degradações ambientais severas acarretadas pelo ser humano.

Evidencia-se ao analisar todos os estados do Brasil que, o Ceará apresenta-se com uma das mais significativas áreas desertificadas. Neste Estado, 14 municípios de um total de 184 abrangem 3 núcleos distintos de desertificação, denominados de Inhamuns, Irauçuba e Jaguaribe. O núcleo de desertificação dos Inhamuns, foco desse artigo, localizado na região centro-oeste do estado do Ceará, apresenta-se em sua maior porção, com graves níveis de desertificação, contemplando grandes áreas degradadas ${ }^{4}$.

São notórias e relevantes as publicações que contêm informações, sobre as características físicas ou naturais de paisagens no estado do Ceará. Contudo, ainda se observam algumas importantes áreas, como o núcleo de desertificação dos Inhamuns e o seu entorno, que possibilitam agregar pesquisas, que descrevam e analisem detalhadamente suas diferentes paisagens, por meio de evidências constatadas em campo e de imagens de satélite.

Observa-se no núcleo dos Inhamuns, algumas características naturais predominantemente homogêneas, a exemplo dos fatores clima e vegetação. Nesse núcleo, o fator clima, apresentase com temperaturas máximas anuais de aproximadamente $32^{\circ} \mathrm{C}$, as mínimas temperaturas anuais de aproximadamente $23^{\circ} \mathrm{C}$ e as médias anuais de temperaturas ficando em torno de $27^{\circ} \mathrm{C}$. As chuvas variam de $300 \mathrm{~mm}$ a $1000 \mathrm{~mm}^{\text {anuais }}{ }^{5}$, prevalecendo três a quatro meses chuvosos e nove a oito meses com totais pluviométricos insignificantes ou de seca ${ }^{6}$. Além disso, esse núcleo tem como principais sistemas atmosféricos produtores de instabilidades atuantes, a Zona de Convergência Intertropical (ZCIT), os Vórtices Ciclônicos de Altos Níveis (VCAN), os Distúrbios Ondulatórios de Leste (DOL), as Linhas de Instabilidade (LI) e os Complexos Convectivos de Mesoescala $(\mathrm{CCM})^{7}$. Com relação ao fator vegetação, observa-se que o núcleo é representado primordialmente pela vegetação caatinga. Esta vegetação tem relação direta com as condições climáticas atuantes, evidenciando-se espécies caducifólias, cactáceas e espinhosas, adaptadas aos baixos índices pluviométricos anuais e as altas temperaturas ${ }^{8}$.

No atual artigo tem-se como objetivo aprofundar o entendimento sobre as características físicas da área desertificada dos Inhumuns e do seu entorno, a partir de uma discussão sobre cada paisagem identificada, setorizada e representada em um mapa com escala de 1:250.000, elaborado com base em imagens Shuttle Radar Topografy Mission (SRTM), com resolução espacial de 30 metros (Earth Explorer - U.S Geological Survey) e através da utilização do software Arcgis (ESRI).

\footnotetext{
${ }^{4}$ Secretaria dos Recursos Hídricos - CEARÁ, $2010 \quad<$ http://www.mpce.mp.br/wpcontent/uploads/2016/05/PROGRAMA-ESTADUAL-DE-COMBATE-ADESERTIFICA\%C3\%87\%C3\%830.pdf>

${ }^{5}$ Aderaldo, $2019<$ http://repositorio.unicamp.br/handle/REPOSIP/333792>.

${ }^{6}$ Zanella, 2007; Instituo Nacional de Meteorologia - INMET, $2020<$ https://mapas.inmet.gov.br/>.

${ }^{7}$ Cavalcanti, 2009.

${ }^{8}$ Ab'Saber, 1974.
} 


\section{Área de Estudo}

A área de estudo foi delimitada com propósito de abranger diferentes paisagens, mostrando peculiaridades que vão além das encontradas nas porções desertificadas, possibilitando entender com maior clareza o contexto físico geral em que se encontram.

Contempla-se na área de estudo o núcleo de desertificação dos Inhamuns, onde se situam os municípios de Independência, Tauá e Arneiroz, bem como suas áreas vizinhas abrangendo os municípios de Boa Viagem, Quixeramobim, Pedra Branca, Mombaça, Senador Pompeu, Acopiara, Jucás, Saboeiro, Catarina, Parambu, Quiterianópolis, Novo Oriente, Crateús, Tamboril e Monsenhor Tabosa, todos localizados no estado do Ceará, Brasil (figura 1).

Figura 1. Mapa de Localização da Área de Estudo

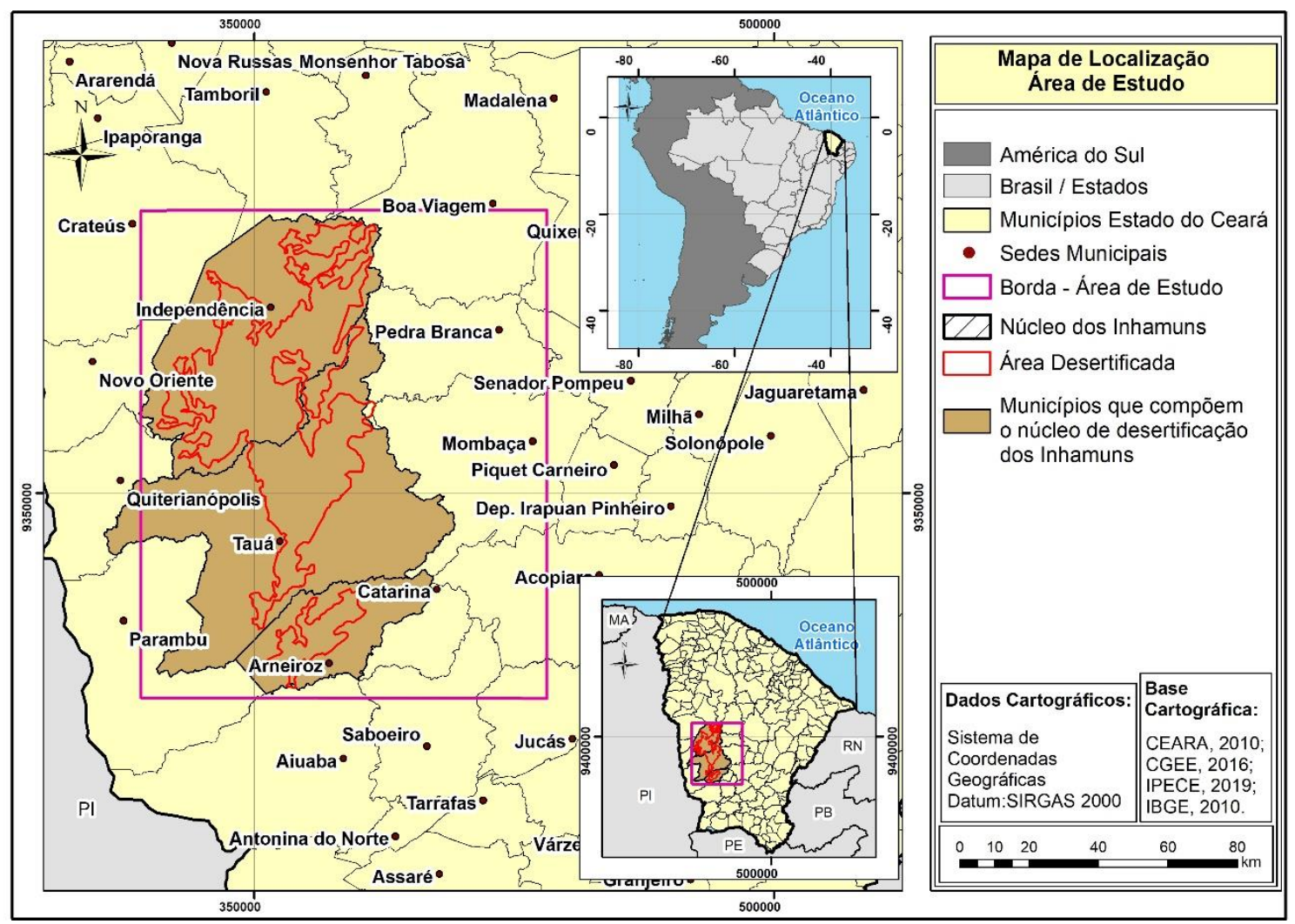

Fonte: Elaboração própria.

A formação dos núcleos de desertificação, observados no estado do Ceará, são desencadeados predominantemente pela ação antrópica e climática, a partir das práticas não sustentáveis, interligadas às condições semiáridas vigentes, que permitem altas taxas de evapotranspiração e baixas médias pluviométricas ${ }^{9}$. No núcleo dos Inhamuns, há presença de um relevo maduro, com marcas de ciclos erosivos, sobre o embasamento cristalino, delineando duas principais formas existentes. A primeira com baixos níveis altimétricos (128 a 392 metros) e de declividades ( 0 a 12 graus), compostas por depressão sertaneja e planícies. A segunda com altos

\footnotetext{
${ }^{9}$ Secretaria dos Recursos Hídricos, CEARÁ, $2010 \quad<$ http://www.mpce.mp.br/wpcontent/uploads/2016/05/PROGRAMA-ESTADUAL-DE-COMBATE-ADESERTIFICA\%C3\%87\%C3\%830.pdf >.
} 
níveis altimétricos (393 a 1138 metros) e de declividade (13 a 73 graus), compostas por cristas, inselbergs e maciços residuais (figura 2).

Figura 2. Núcleos de desertificação presentes no estado do Ceará

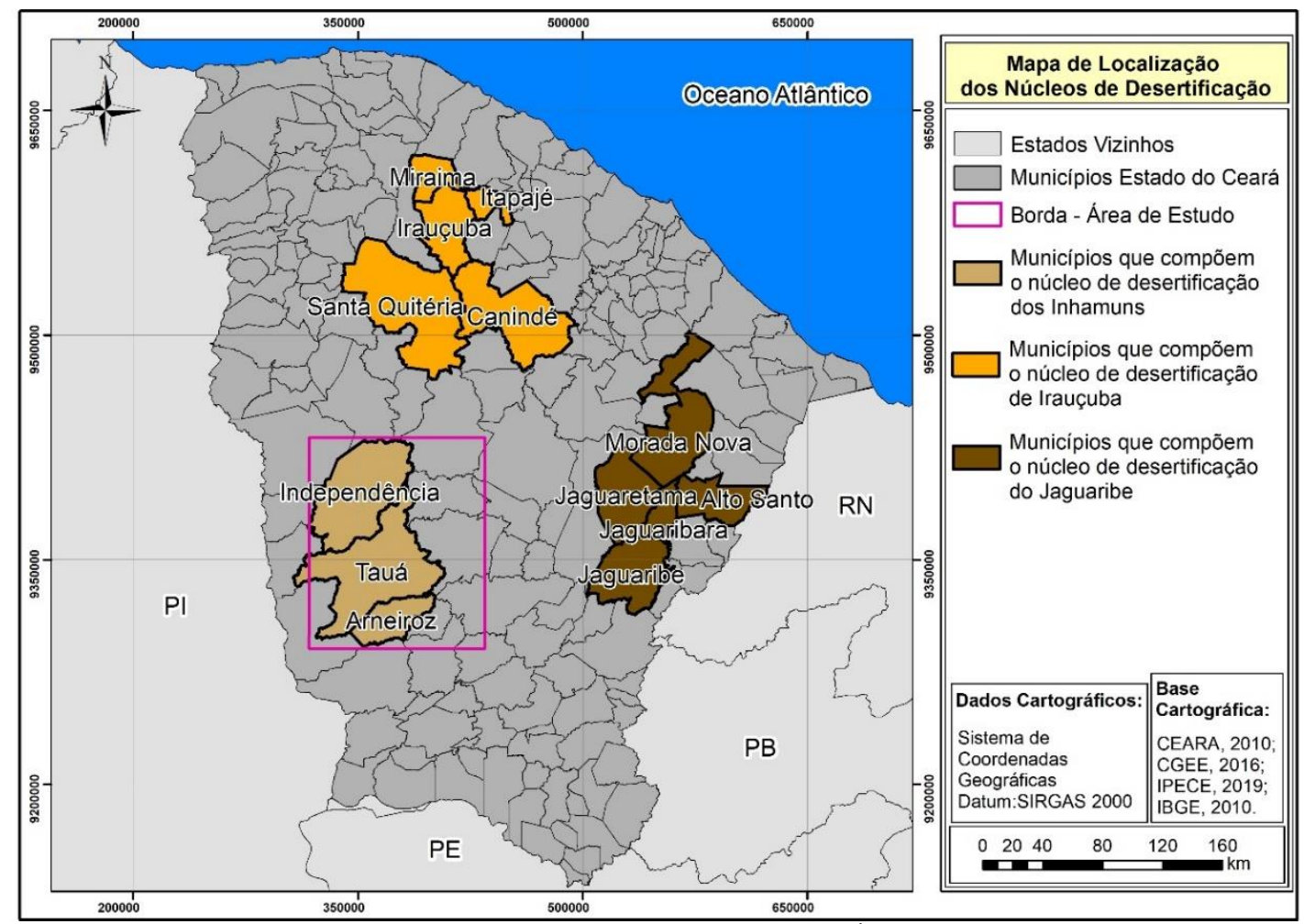

Fonte: Elaboração própria; Secretaria dos Recursos Hídricos, CEARÁ, $2010<$ http://www.mpce.mp.br/wpcontent/uploads/2016/05/PROGRAMA-ESTADUAL-DE-COMBATE-A-

DESERTIFICA\%C3\%87\%C3\%83O.pdf >.

\section{Materiais Utilizados e Metodologia}

O termo paisagem utilizado neste artigo remete-se ao entendimento interacional de processos atuais e passados, em uma determinada porção do espaço, resultante de uma combinação dinâmica, entre os seus elementos constituintes, tais como os físicos, biológicos e antrópico, que formam um conjunto único e indissociável, em perpétua evolução ${ }^{10}$. Nesse contexto, utilizar o termo paisagem mostra-se satisfatório, dado que as discussões realizadas sobre as características físicas da área desertificada, envolve-se por diversas relações de interdependências entre os seus elementos constituintes, nos quais são mutáveis ao longo do tempo, e formadores de um conjunto complexo com características singulares.

Para setorização das paisagens presentes na área de estudo, realiza-se nestas, uma divisão ou compartimentação a partir dos critérios topográficos e das formas de relevo, nas quais, apresentam-se com traços em comuns quanto às suas características fisionômicas e genéticas ${ }^{11}$.

\footnotetext{
${ }^{10}$ Bertrand, $2004<$ https://revistas.ufpr.br/raega/article/view/3389>.

${ }^{11}$ Souza, 2000.
} 
Denomina-se neste artigo, cada paisagem setorizada a partir desses critérios, como compartimento do relevo.

Para execução do mapa de compartimentação do relevo, no software Arcgis (ESRI), realizouse atividades de campo para identificar feições do relevo, explorou-se mapas geológicos realizados pela Companhia de Pesquisa e Recursos Minerais (CPRM) ${ }^{12}$, e analisou-se imagens Shuttle Radar Topografy Mission (SRTM), com resolução espacial de 30 metros, retiradas no site Earth Explorer - U.S Geological Survey, com cartas de seguintes nomeações: S05-W0401ARCV3; S05-W041-1ARC-V3; S06-W040-1ARC-V3; S06-W041-1ARC-V3; S06-WP421ARC-V3; S07-W040-1ARC-V3; S07-W041-1ARC-V3. O mapa com a setorização dos compartimentos, teve como escala de mapeamento 1:250.000 e como escala de representação 1:500.000 (quadro 1).

Quadro 1. Dados especificando as características das SRTM utilizadas

\begin{tabular}{|c|c|}
\hline \multicolumn{2}{|l|}{ Especificações do produto } \\
\hline Projeção & Geográfica \\
\hline Datum Horizontal & WGS84 \\
\hline Datum Vertical & EGM96 (Earth Gravitational Model 1996) \\
\hline Unidadesverticais & Metros \\
\hline Resolução especial & $\begin{array}{l}\text { 1segundo de arco para cobertura global }(\sim 30 \\
\text { metros) } \\
3 \text { segundos de arco para cobertura global }(\sim 90 \\
\text { metros) }\end{array}$ \\
\hline Tamanha Raster & Telhas de 1 grau \\
\hline Comprimento de onda de banda $\mathrm{C}$ & $5,6 \mathrm{~cm}$ \\
\hline
\end{tabular}

Posterior setorização nas paisagens, discorre-se sobre suas características físicas e antrópicas predominantes. O embasamento para descrição dessas características, deu-se a partir das atividades de campo e da consulta aos seguintes dados base: mapeamento geológico do estado do Ceará, realizado pela CPRM ${ }^{13}$, na escala de 1:500.000; mapeamento da vegetação do Brasil, realizado pelo Instituto Brasileiro de Geografia e Estatística (IBGE) ${ }^{14}$, na escala de 1:250.000; mapeamento de solos do estado do Ceará, realizado em meio digital, pela Empresa Brasileira de Pesquisas Agropecuárias (EMBRAPA) ${ }^{15}$, na escala de 1:600.000; mapeamento de cursos hídricos e bacias hidrográficas do estado do Ceará, realizado de Companhia de Gestão dos Recursos Hídricos do Ceará $(\mathrm{COGERH})^{16}$, na escala de 1:100.000; Compartimentação Geoambiental do estado do Ceará, realizado pela FUNCEME ${ }^{17}$, na escala de 1:600.000; Censo Agropecuário 2017 ${ }^{18}$; Estudos Técnicos sobre desertificação na área de estudo ${ }^{19}$. Dando suporte

\footnotetext{
${ }^{12}$ Companhia de Pesquisa de Recursos Minerais, CPRM, $2003<$ http://rigeo.cprm.gov.br/jspui/handle/doc/2355>.

${ }^{13}$ Companhia de Pesquisa de Recursos Minerais, CPRM, 2003 <http://rigeo.cprm.gov.br/jspui/handle/doc/2355>

${ }^{14}$ Instituto Brasileiro de Geografia e Estatística - IBGE, $2019<\mathrm{https}$ ://www.ibge.gov.br/geociencias/downloadsgeociencias.html>.

${ }^{15}$ Empresa Brasileira de Pesquisa Agropecuária - EMBRAPA, 1973

$<$ http://www.uep.cnps.embrapa.br/solos/index.php?link=ce>.

${ }^{16}$ Companhia de Gestão dos Recursos Hídricos - COGERH, 2019 <http://atlas.cogerh.com.br/>.

${ }^{17}$ Fundação Cearense de Meteorologia e Recursos Hídricos - FUNCEME, 2009.

${ }^{18}$ Brasil, 2017 <https://censoagro2017.ibge.gov.br/templates/censo_agro/resultadosagro/index.html〉.

${ }^{19}$ CCGE, 2016 <https://www.cgee.org.br/documents/10195/734063/DesertificacaoWeb.pdf>.
}

Secretaria dos Recursos Hídricos - CEARÁ, 2010 <http://www.mpce.mp.br/wpcontent/uploads/2016/05/PROGRAMA-ESTADUAL-DE-COMBATE-A-

DESERTIFICA\%C3\%87\%C3\%83O.pdf >. 
aos supracitados dados em distintas escalas, utilizaram-se também, a fim de minimizar algum erro, estudos realizados nesse viés que englobam todo o Estado do Ceará ${ }^{20}$.

\section{Resultados}

Os compartimentos do relevo, observados na figura 3, se inserem em dois grandes domínios morfoestruturais. Um deles, representado pelos escudos e maciços cristalinos, compostos pelas depressões sertanejas, maciços residuais, cristas e inselbergs. Salienta-se que nesse domínio, houve uma divisão no compartimento da depressão sertaneja, com objetivo de uma maior especificação na discussão e no mapeamento, visto a presença de um significativo desnível topográfico.

O outro domínio representado pelos depósitos cenozoicos sedimentares, é composto pela planície fluvial, a qual é caracterizada como uma área de exceção no contexto semiárido, por apresentar dentre outros, maior disponibilidade hídrica e vegetação predominantemente de maior porte com presença de folhagem na coloração verde.

\section{Figura 3. Mapa de Compartimentos do Relevo}

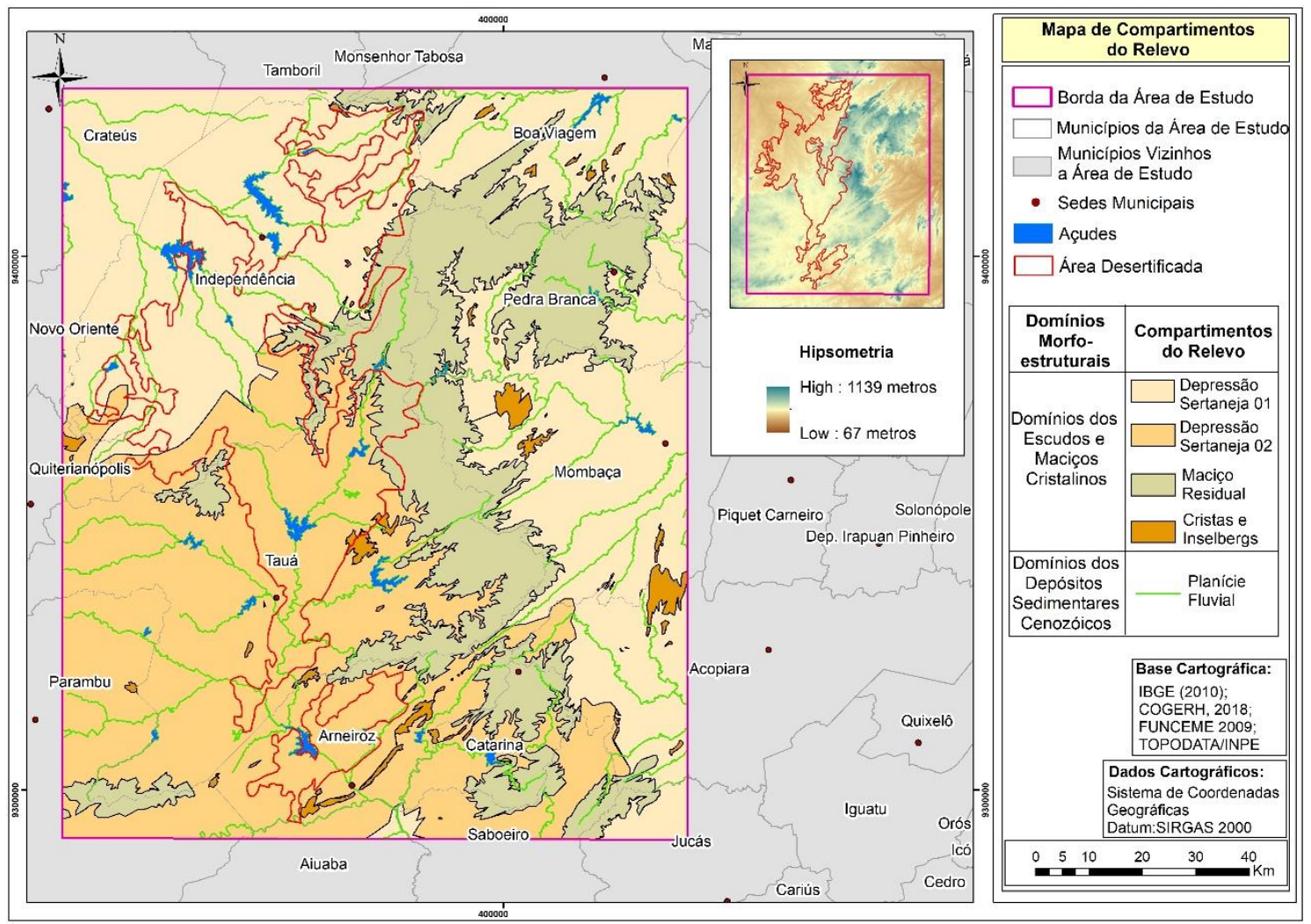

Fonte: Elaboração própria

Percebe-se também na figura 3, que a depressão sertaneja representa o compartimento com a maior porção de área desertificada. Essas depressões, se constituem por superfícies de aplainamento, cujos processos de dissecação são comandados, por atuação principalmente

\footnotetext{
${ }^{20}$ Brandão, 2014 <http://rigeo.cprm.gov.br/xmlui/handle/doc/16726>; Souza, 2000.
} 
fluvial que seguem as direções tectônicas, marcadas por estruturas do embasamento cristalino ${ }^{21}$. As marcas de degradação nesse compartimento, são motivadas pelas práticas predatórias, tais como, queimadas, extrativismo vegetal e pecuária extensiva, ao longo de décadas ${ }^{22}$. Como consequência dessas ações degradadoras, nota-se a configuração de porções desertificadas, com as seguintes características, inexistência de potencial agrícola, carência de animais silvestres, marcas de erosão e solos rasos, manto de intemperismo com nítidos pontos de afloramento rochoso, insignificância ou inexistência de corpos hídricos e vegetação caatinga totalmente degradada ou inexistente (figuras 4 e 5).

Figura 4. Manto de intemperismo com nítidos pontos de afloramento rochoso e marcas de erosão, bem como, inexistência de corpos hídricos e efetiva cobertura vegetal

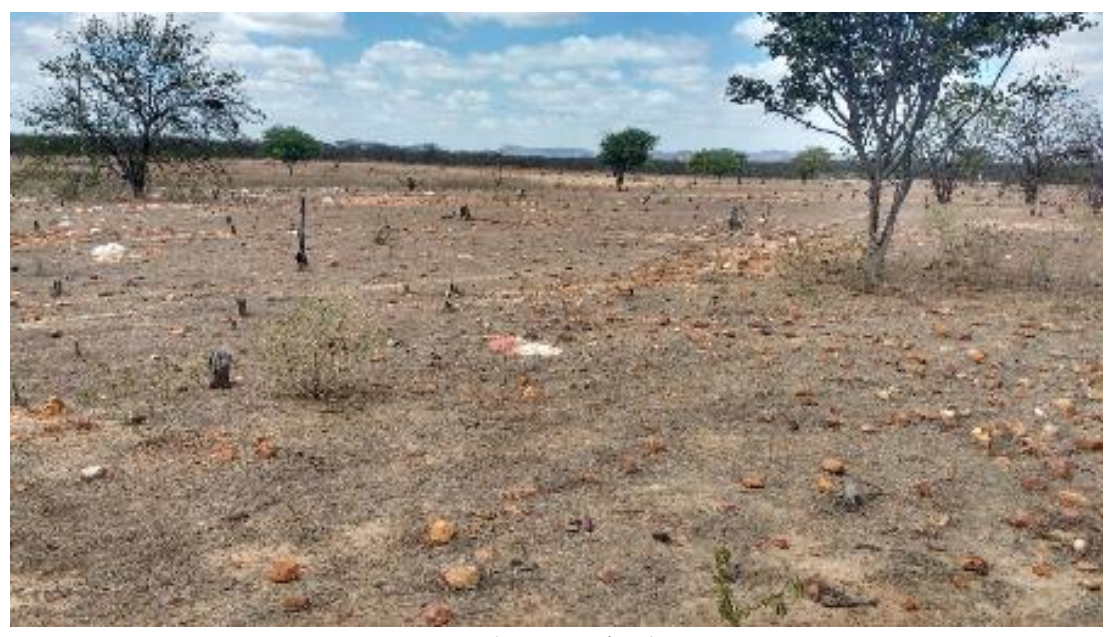

Fonte: Acervo do Autor.

Figura 5. Manto de intemperismo com nítidos pontos de afloramento rochoso e marcas de erosão, bem como, inexistência de corpos hídricos e efetiva cobertura vegetal

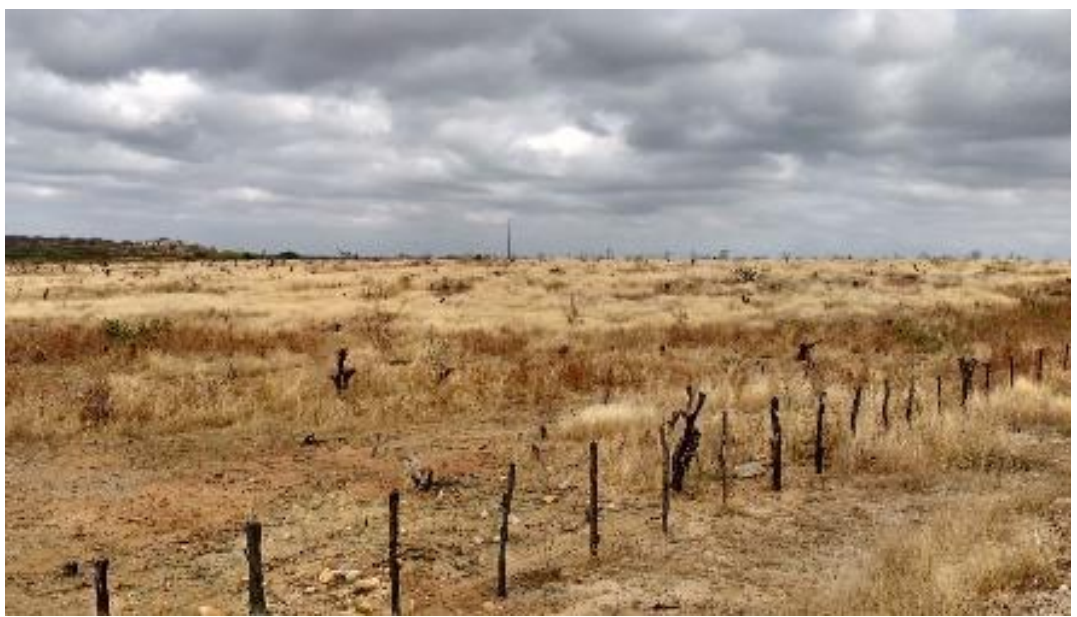

Fonte: Acervo do Autor.

\footnotetext{
${ }^{21}$ Costa, Maia, Barreto e Sales, $2020<$ http://www.lsie.unb.br/rbg/index.php/rbg/article/view/1447>; Maia e Bezerra, 2014.

${ }^{22}$ CCGE, 2016 <https://www.cgee.org.br/documents/10195/734063/DesertificacaoWeb.pdf>.
} 
Nessa perspectiva, contribuições ambientais sobre essas paisagens e o seu entorno, tornam-se de significativa relevância, uma vez que, servirão para embasar futuras pesquisas que envolvam planejamento do território e práticas sustentáveis.

Discute-se nos próximos tópicos as respectivas características físicas dominantes dos compartimentos presentes na área de estudo, conciliando-se sempre que possível com registros fotográficos.

\section{Depressão Sertaneja}

Na Depressão Sertaneja, evidencia-se prevalência de processos de dissecação sobre os de deposição, propiciando exposição do embasamento cristalino e formação de vastos pediplanos dissecados que se encaixam nos maciços residuais, inselbergs, cristas e planícies fluviais ${ }^{23}$. Os rios presentes são os intermitentes sazonais de padrões dendríticos, e o seu clima é o semiárido com altas temperaturas e reduzido período chuvoso. Nesse compartimento também se identificam solos rasos e poucos profundos, sendo predominantes os Luvissolo Crômico, Planossolo Háplico e Neossolo Regolítico. É comum nesses solos a presença destacada de um pavimento desértico ou pedregoso ${ }^{24}$. A vegetação presente na depressão sertaneja, configurase do tipo xerófita com aspecto moldado ao ciclo pluviométrico anual, observando-se no período seco, árvores sem folhas com aparência de mortas, e no período chuvoso, árvores com folhas verdes e adensadas. Essa grande resiliência na caatinga, quando há intensificação da chuva, expõe-se como marca peculiar desse compartimento ${ }^{25}$.

Os usos dos solos nesse compartimento, notados em imagens disponibilizadas no software Google Earth, em atividades de campo e em dados do censo agropecuário, são primordialmente agropecuaristas. Na agricultura, constata-se produção de milho, feijão, mandioca, cana de açúcar e algodão herbáceo e na pecuária destaca-se a produção de bovinos e caprinos ${ }^{26}$.

A Depressão Sertaneja, principal palco das situações analisadas na área de estudo, têm suas superfícies pediplanadas em dois níveis, uma com cotas variando entre 392 a 495 metros acima do nível do mar, denominada de depressão sertaneja 02 - DP02, e outra com cotas variando entre 128 a 392 metros acima do nível do mar, denominada de depressão sertaneja 01 - DP01 (figura 6).

\footnotetext{
${ }^{23}$ Maia e Bezerra, 2014.

${ }^{24}$ Brandão, 2014 <http://rigeo.cprm.gov.br/xmlui/handle/doc/16726>.

${ }^{25}$ Souza, 2000.

${ }^{26}$ Brasil, 2017 <https://censoagro2017.ibge.gov.br/templates/censo_agro/resultadosagro/index.html>.
} 
Figura 6. Área de contato entre as depressões 01 e 02, no município de Independência, Ceará e inserida no núcleo de desertificação

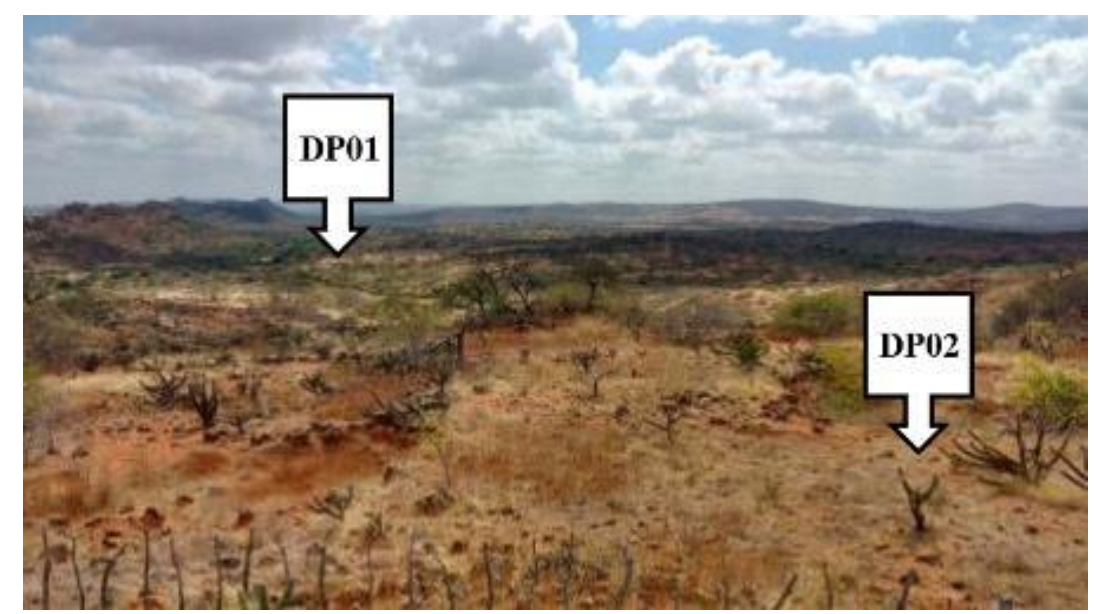

Fonte: Acervo do Autor.

Nota-se ao fundo a DP01 mais rebaixada, quando comparada a DP02 mais elevada e com marcas de entalhe pela drenagem.

Ambas as depressões têm seu embasamento formado por rochas ígneo-metamórficas do PréCambriano, com presença de pediplanos bem elaborados e com vastas superfícies arrasadas ${ }^{27}$.

Na DP01, há domínio do intemperismo físico, calcado em processos de erosão por escoamento superficial difuso e concentrado em fluxo de enxurrada. Na DP02, percebe-se maiores porções de dissecações que obedecem aos lineamentos estruturais e zonas de cisalhamento ${ }^{28}$. Na área desertificada presente na DP02, por existir corriqueiras áreas de afloramento do cristalino, identifica-se significativos traços de dissecamentos, seguindo o padrão da zona de cisalhamento brasiliano (N-S; NE-SW) ${ }^{29}$ (figura 7).

Figura 7. Traços de dissecação, presente no município de Tauá, Ceará

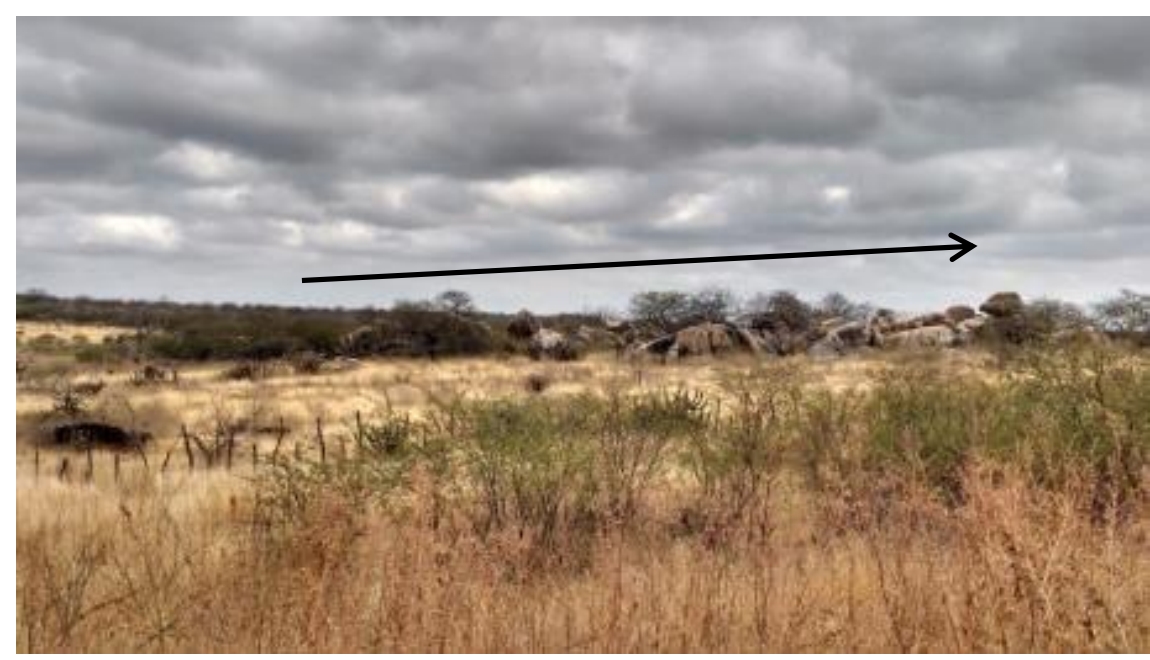

Fonte: Acervo do Autor.

\footnotetext{
${ }^{27}$ Brandão, 2014 <http://rigeo.cprm.gov.br/xmlui/handle/doc/16726>.

${ }^{28}$ Brandão, $2014<$ http://rigeo.cprm.gov.br/xmlui/handle/doc/16726>.

${ }^{29}$ Maia e Bezerra, 2014.
} 
De modo geral prevalecem nas depressões sertanejas suaves declividades, verificando-se apenas duas principais áreas com grandes declives, representadas pelas áreas de contato com os compartimentos mais elevados ou rampas de colúvios e pelas áreas de vales entalhados pelas drenagens. Nessas áreas de vales, há maior prevalência de acúmulo hídrico e formação de planícies fluviais, sendo comumente evidenciadas com diversos usos agrícolas ${ }^{30}$.

\section{Maciços Residuais}

Os maciços residuais, que se constituem de rochas mais resistentes que as do seu entorno rebaixado, são resultados da exumação de intrusões plutônica em regiões extensionais associadas a estruturas tectônicas ${ }^{31}$. Esses maciços apresentam-se com áreas de nascentes que formam importantes rios no estado do Ceará, tais como o Banabuiú e o Poti, que drenam até mesmo a outros Estados e ao Oceano Atlântico ${ }^{32}$. Seu clima é o semiárido, contudo mostrandose sobre o efeito da atitude, na qual interfere numa pequena redução em suas temperaturas médias, quando comparada com as evidenciadas nas outras porções da área de estudo, a exemplo da depressão sertaneja.

Nesse compartimento identifica-se predomínio de solos rasos, de textura arenosa, associada presença de pedregosidade, tais como os Neossolos Litólicos, mas constata-se também em menor frequência, solos profundos, bem drenados e de boa fertilidade, tais como os Argissolos Vermelho-Amarelos eutróficos. Este compartimento se caracteriza pela vegetação caatinga, mostrando-se mais adensada e com porte variando de médio a alto ${ }^{33}$. Os principais usos dos solos nos maciços residuais são representados pela agropecuária e mineração de granitos ${ }^{34}$.

Tem-se como maior exemplo desse compartimento na área de pesquisa, o maciço de Pedra Branca (porção central), que se manifesta por litologia Pré-Cambriana, com rochas ígneometamórficas. Por ter grande extensão e ter maior elevação quando comparado ao piso regional de menores cotas, é facilmente identificado ao percorrer as depressões sertanejas.

Os maciços residuais apresentam-se com acentuada inclinação em suas extremidades, configurando-se com formas elevadas e marcadas por forte dissecação, destacando a atuação da erosão diferencial. Suas atitudes variam de 495 metros a 1138 metros, proporcionando barreiras orográficas entre a depressão sertaneja e ocasionando distintas condições naturais a barlavento e a sotavento.

Em suas porções centrais, observam-se vários vales com rampas coluviais, associados a superfícies com nítidos fronts e reversos, que se assemelham a pequenas serras ou a zonas de abaulamentos $^{35}$ (figura 8).

\footnotetext{
${ }^{30}$ Fundação Cearense de Meteorologia e Recursos Hídricos - FUNCEME, 2009.

${ }^{31}$ Costa, Maia, Barreto e Sales, $2020<\mathrm{http}$ ///www.lsie.unb.br/rbg/index.php/rbg/article/view/1447>.

${ }^{32}$ Companhia de Gestão dos Recursos Hídricos - COGERH, 2019 <http://atlas.cogerh.com.br/>.

${ }^{33}$ Brandão, $2014<$ http://rigeo.cprm.gov.br/xmlui/handle/doc/16726>.

${ }^{34}$ Fundação Cearense de Meteorologia e Recursos Hídricos - FUNCEME, 2009.

${ }^{35}$ Aderaldo, 2019 <http://repositorio.unicamp.br/handle/REPOSIP/333792>.
} 
Figura 8. Vales com rampas coluviais no Maciço Residual de Pedra Branca, em Boa Viagem, Ceará

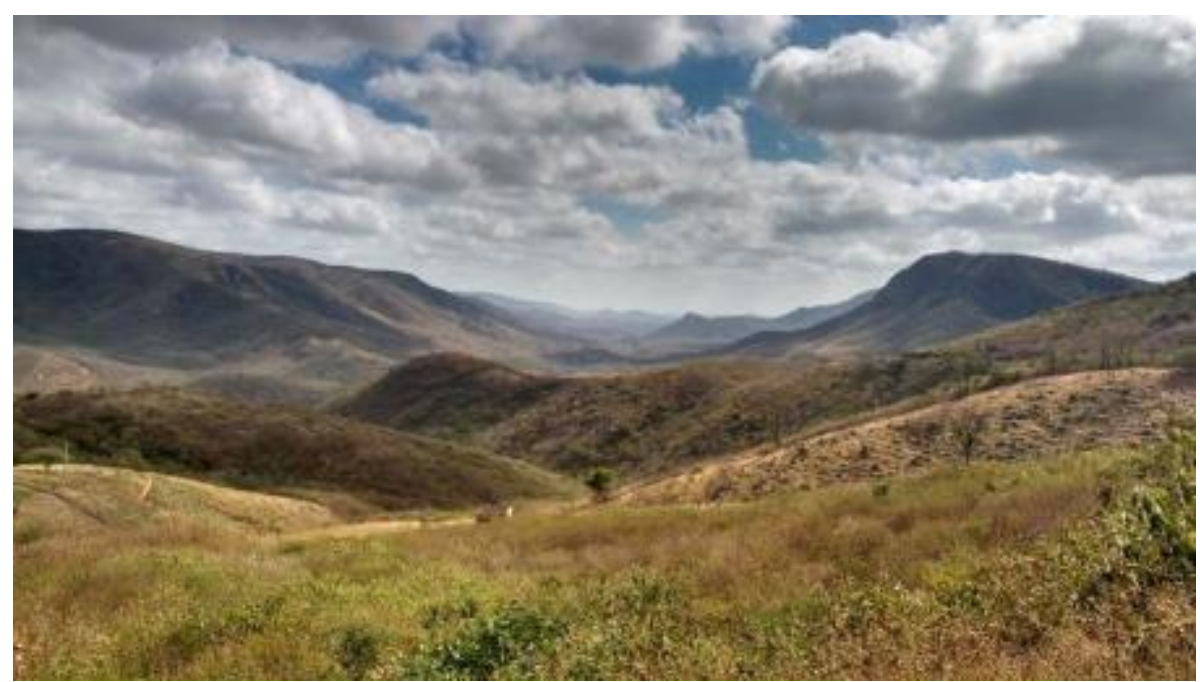

Fonte: Acervo do autor.

Nota-se anfiteatros nas bordas dos maciços, ou seja, feições semicirculares, com entradas e saídas que formam nítidas ondulações no front da vertente, ocasionadas pela erosão predominantemente fluvial. Esses anfiteatros, se associam em diversos setores, à formação de vales que adentram o maciço residual sem grandes declives (figura 9). Visualizam-se também algumas vertentes dos maciços residuais com superfícies escalonadas, diferenciando-as das vertentes predominantes com elevações contínuas e sem rupturas (figura 10).

Figura 9. Anfiteatro associado à formação de vales que adentram no sentido da seta preta no Maciço de Pedra Branca, em Mombaça, Ceará

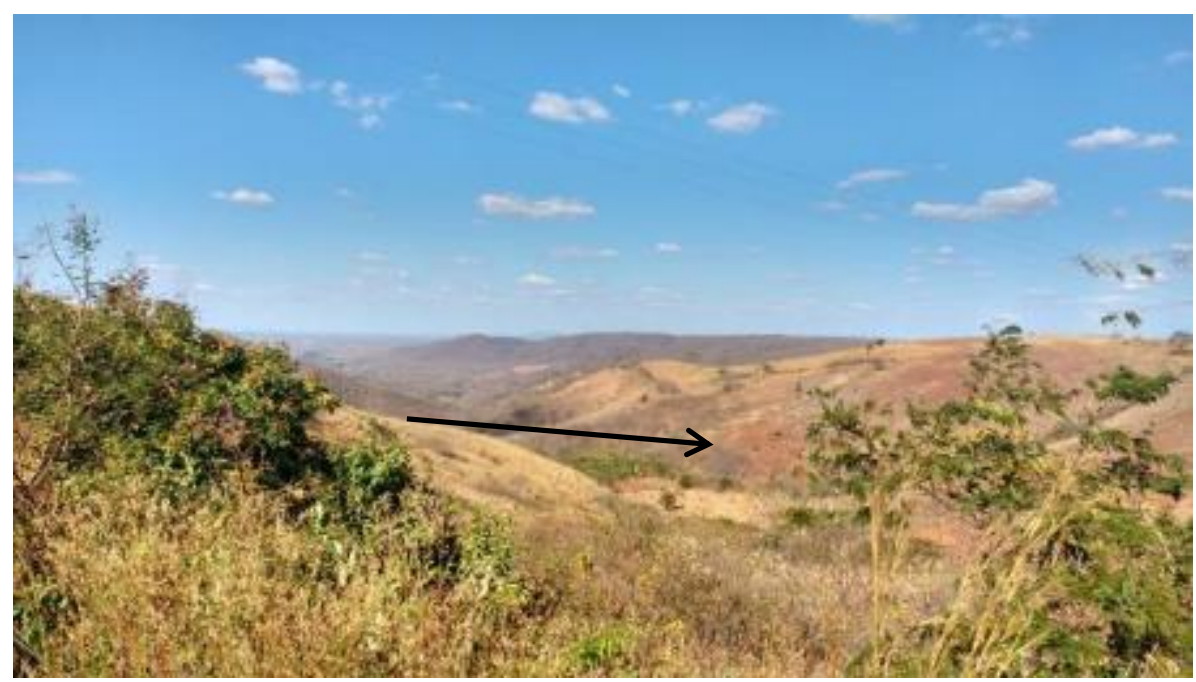

Fonte: Acervo do autor. 


\section{Figura 10. Bordas com superfícies escalonadas no Maciço de Pedra Branca, em Boa Viagem, Ceará. Setas pretas indicando os distintos patamares}

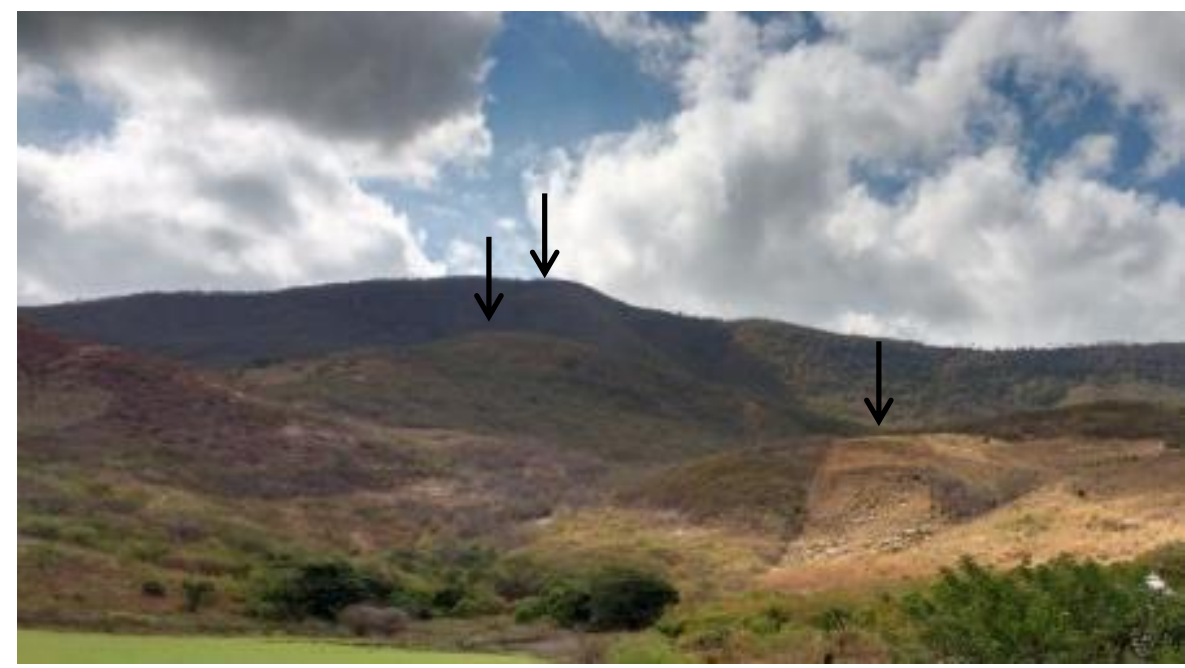

Fonte: Acervo do autor.

Salienta-se que, por não apresentarem porções com florestas úmidas, tais como observado em distintos relevos no estado do Ceará, a exemplos no Maciço Residual de Guaramiranga, Planalto da Ibiapaba e na Chapada do Araripe, os maciços identificados na área de estudo, não são considerados com a presença de brejo de altitude. Os brejos de altitude constatados na região Nordeste do Brasil, configuram-se com encraves de mata atlântica, cercados por vegetação caatinga. A formação dessa floresta úmida, presente nos brejos, relaciona-se inicialmente com o seu avanço sobre as caatingas, em momentos interglaciais ocorridos durante o Pleistoceno, e posteriormente com o seu recuo sobre as caatingas, após período interglacial, prevalecendo apenas resquícios fragmentados e isolados em locais onde se tinha microclimas favoráveis ${ }^{36}$.

\section{Cristas e Inselbergs}

O compartimento de Cristas e Inselbergs apresentam-se pelos litotipos variados do Complexo Cristalino, com predominância de rochas mais resistentes ao trabalho da erosão ${ }^{37}$. Quando comparado ao compartimento dos maciços residuais, assemelham-se por estarem rodeados pelas depressões sertanejas e por exibirem níveis altimétricos significativos, mas diferenciamse por revelar uma maior atuação da dissecação em suas vertentes, proporcionado o respectivo recuo paralelo e consequentemente apresentando-se com menores dimensões na paisagem.

O processo de formação desse compartimento, iguala-se aos ocorridos em maciços residuais, ainda que se mostrem mais erodidos pelo clima. Evidencia-se nesse compartimento clima semiárido, drenagem com padrões dendríticos e escoamento intermitente sazonal, predominância de Neossolos Litólicos e afloramento rochoso, com vegetação rupestre ou de médio porte ${ }^{38}$. Acredita-se que, por existir nesse compartimento, vertentes íngremes, solos rasos

\footnotetext{
${ }^{36}$ Andrade-Lima, 2007 <https://ainfo.cnptia.embrapa.br/digital/bitstream/item/34635/1/AAPCA-V4-Artigo01.pdf $>$.

Porto, Cabral e Tabarelli, 2004.

${ }^{37}$ Companhia de Pesquisa de Recursos Minerais - CPRM, 2003 <http://rigeo.cprm.gov.br/jspui/handle/doc/2355>.

${ }^{38}$ Fundação Cearense de Meteorologia e Recursos Hídricos - FUNCEME, 2009; Souza, 2000.
} 
e com baixa fertilidade, não se constata significativos usos e ocupações do solo, sendo evidenciado apenas marcas pretéritas de extrativismo vegetal especificadamente da madeira.

As cristas são caracterizadas com formas alongadas e retilíneas, escarpas bem acentuadas, modesta superfície de cimeira e altitudes próximas das encontradas em maciços residuais (figura 11).

Figura 11. Cristas Residuais indicadas pela seta preta em Mombaça, Ceará

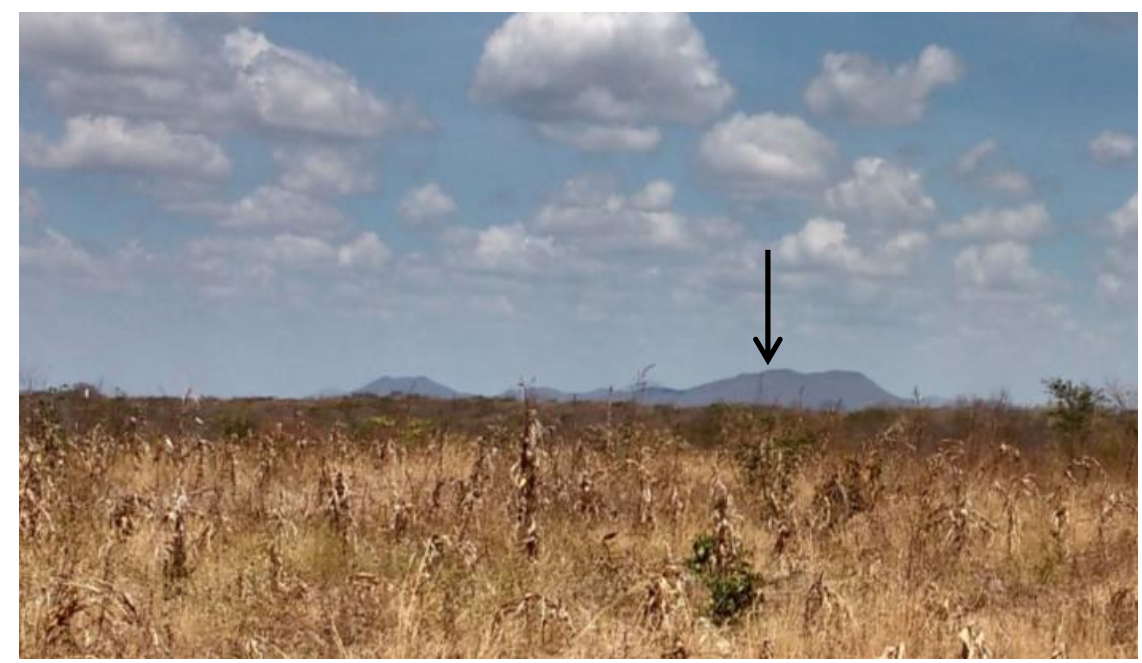

Fonte: Acervo do autor.

Os Inselbergs exibem-se com formas onduladas e não retilíneas, com presenças de afloramentos rochosos, com níveis altimétricos mais suaves quando comparados aos maciços residuais, e com marcas de termoclastia (figura 12).

Figura 12. Inselbergs indicados pelas setas pretas em Tauá, Ceará

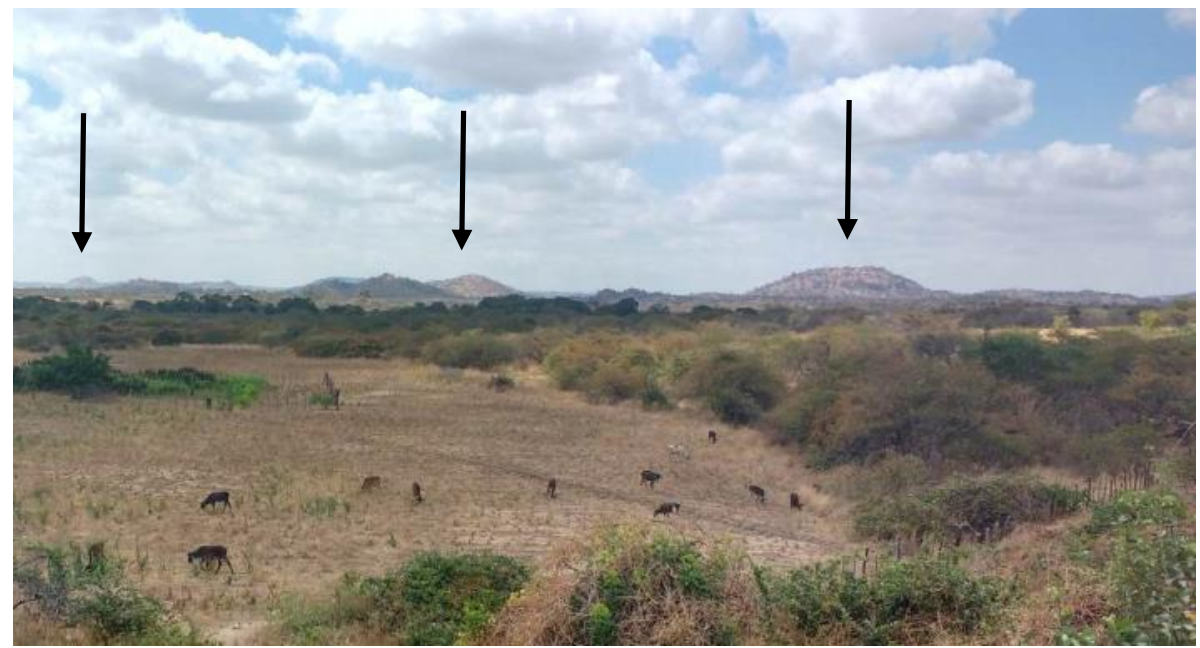

Fonte: Acervo do Autor. 


\section{Planícies Fluviais}

$\mathrm{Na}$ área de estudo, identificam-se três bacias hidrográficas, denominadas Banabuiú, Sertões de Crateús e Alto Jaguaribe. Nessas bacias os rios com maiores destaques, formando importantes áreas de planícies fluviais, são: Poti, Cupim, Quixeramobim, e Banabuiúu ${ }^{39}$.

As planícies fluviais são as formas mais características de acumulação e deposição decorrentes da ação fluvial, apresentando-se em seus leitos, sedimentos aluviais. Estas evidenciam-se facilmente em constantes cortes nas depressões sertanejas e são consideradas áreas de exceção ${ }^{40}$, por abrigarem melhores condições de solos e disponibilidade hídrica. No período chuvoso as planícies e os terraços mais elevados, são utilizados para plantio de subsistência. No período seco, representam importantes fontes de abastecimento hídrico, através de poços construídos em seus leitos.

Nota-se nesse compartimento que seus escoamentos hídricos se configuram como intermitente sazonal em fluxo muito lento. Sua declividade varia de 0 a 3 graus. Sua erodibilidade, devido sua baixa permeabilidade é alta. Seu clima é o semiárido, contudo mostrando-se com maiores níveis de umidade e menores temperaturas ocasionadas pelo adensamento da vegetação. Seus solos predominantemente são Neossolos Flúvicos, Planossolos Háplicos e Vertissolos, caracterizando-se como profundos, contendo camadas estratigráficas com distribuição irregular da granulometria. Sua vegetação é composta pelas matas ciliares, com predominância de folhagens verdes inclusive no período $\mathrm{seco}^{41}$.

Esse compartimento exibe-se com áreas planas em faixas de aluviões recentes e com baixadas inundáveis. Sua altimetria, marcada pelos constantes entalhes, corresponde a mais baixa quando comparada aos outros compartimentos. Seu aspecto com vegetações verdes refere-se a uma típica característica e a uma predisposição para sua identificação nas áreas semiáridas ${ }^{42}$ (figura 13).

\section{Figura 13. Talvegue do rio Carrapateiras sem água, mas com vegetação ciliar verde e densa, presente no município de Tauá, Ceará}

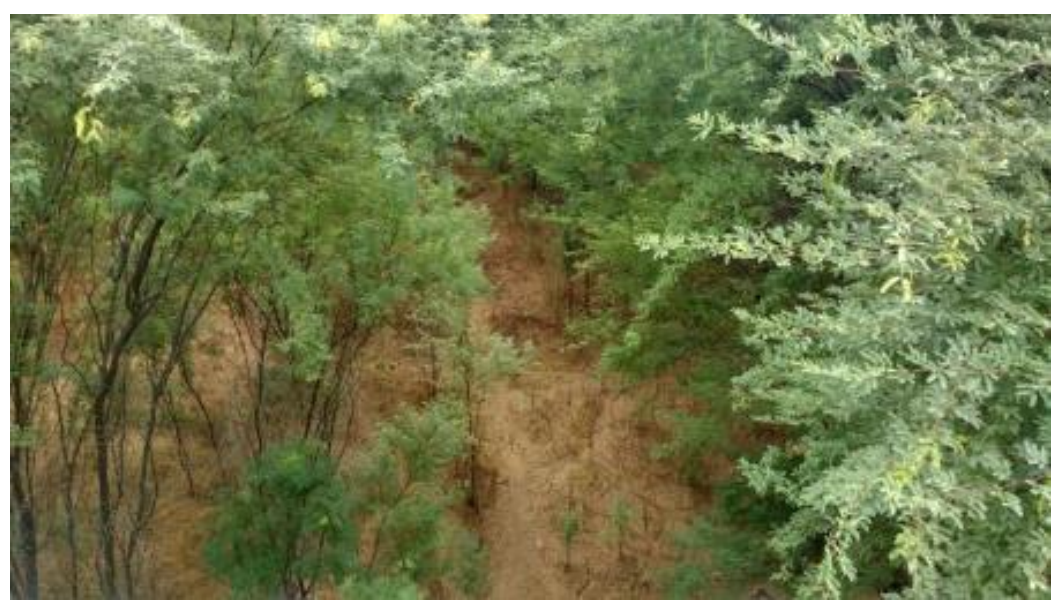

Fonte: Acervo do Autor.

\footnotetext{
${ }^{39}$ Gestão dos Recursos Hídricos - COGERH, 2019 <http://atlas.cogerh.com.br/>.

${ }^{40} \mathrm{Ab}$ 'Saber, 1999 < http://www.revistas.usp.br/eav/article/view/9474>.

${ }^{41}$ Brandão, $2014<$ http://rigeo.cprm.gov.br/xmlui/handle/doc/16726>.

${ }^{42}$ Ab'Saber, 1974; Souza, 2000.
} 
Identifica-se que grande parte do desenvolvimento das zonas urbanas e rurais foram iniciadas nas proximidades desse compartimento. Nesse sentido, quando há chuvas torrenciais, típicas do semiárido, verificam-se inundações, causando danos para agricultura e para ocupações próximas ao leito. Significativas atividades antrópicas, são observadas degradando esse importante compartimento, tais como, extração de areia do canal, extração de argila pra construção de telhas, esgotos direcionados para os leitos, desmatamentos na mata ciliar causando assoreamento, residências e extensas zonas com agricultura em área de proteção permanente em suas bordas.

\section{Conclusão}

Para que haja um melhor embasamento de futuras pesquisas voltadas para o planejamento ambiental e adequação das práticas de usos e ocupações, torna-se necessário a existência de um levantamento físico das paisagens presentes. Para tal, as imagens de satélite em conjunto com as atividades de campo, foram essenciais neste artigo, facilitando a pesquisa e permitindo a compartimentação do relevo e as respectivas descrições das características naturais.

A análise das imagens de satélites em associação com os dados provindos de atividades de campo, possibilitaram realizar setorização topográfica, constatar zonas de lineamentos estruturais (N-S; NE-SW), identificar planícies, depressões, maciços, cristas e inselbergs, observar com maior clareza os elementos naturais constituintes das paisagens, delimitar os compartimentos no núcleo de desertificação dos Inhamuns e seu entorno, realizar mapa com esses distintos compartimentos, e visualizar ações antrópicas que degradam e colaboram na formação da desertificação.

Acredita-se que as áreas desertificadas no núcleo dos Inhamuns necessitam, cada vez mais, de estudos que busquem revelar as suas atuais condições naturais e de degradação. Isto poderia contribuir a que se legislasse e pusesse em prática políticas de conservação destes ecossistemas, preservando a biodiversidade, restaurando os solos degradados, e combatendo a desertificação.

\section{Referências bibliográficas}

AB'SÁBER, Aziz Nacib. $O$ domínio morfoclimático semiárido das caatingas brasileiras. Geomorfologia. Instituto de Geografia / USP, São Paulo, n. 43, p.1-39, 1974.

AB'SÁBER, Aziz Nacib. Sertões e sertanejos: uma geografia humana sofrida. Estudos avançados, v. 13, n. 36, p. 7-59, 1999.

ADERALDO, Pedro Ítalo Carvalho. Interação do relevo do processo de desertificação: o contexto da desertificação no sertão dos Inhamuns - Ceará. Dissertação de mestrado defendida na Universidade Estadual de Campinas. 2019. 143p. Disponível em: <http://repositorio.unicamp.br/handle/REPOSIP/333792> [Consulta: 21 de agosto de 2019].

ANDRADE-LIMA, Dárdano. Estudos fitogeográficos de Pernambuco. Anais da Academia Pernambucana de Ciência Agronômica, Recife, vol. 4, p. 243-274, 2007. Disponível em:<https://ainfo.cnptia.embrapa.br/digital/bitstream/item/34635/1/AAPCA-V4-Artigo01.pdf> [Consulta: 10 de outubro de 2020]. 
BERTRAND, Georges. Paisagem e geografia física global. Esboço metodológico. Raega - O Espaço Geográfico em Análise. V.8, 2004. 12p. [ISSN 2177-2788]. Disponível em: <https://revistas.ufpr.br/raega/article/view/3389> [Consulta: 10 de outubro de 2020].

BRASIL. Censo agropecuário 2017, Resultados Prévios. IBGE - Instituto Brasileiro de Geografia e Estatística. Rio de Janeiro, 2017. Disponível em: <https://censoagro2017.ibge.gov.br/templates/censo_agro/resultadosagro/index.html> [Consulta: 15 de novembro de 2018].

BRASIL. Programa de ação nacional de combate à desertificação e mitigação dos efeitos da seca: PAN-BRASIL. Edições Ministério do Meio Ambiente / Secretária de Recursos Hídricos. Brasília, DF, 2004. 242p. Disponível em: <https://www.mma.gov.br/estruturas/sedr_desertif/_arquivos/pan_brasil_portugues.pdf> [Consulta: 08 de agosto de 2020].

BRANDÃO, Ricardo de Lima. Geodiversidade do estado do Ceará. Fortaleza: Edições da CPRM, 2014. 214 p. [ISBN 978-85-7499-140-5]. Disponível em: <http://rigeo.cprm.gov.br/xmlui/handle/doc/16726> [Consulta: 16 de março de 2020].

CAVALCANTI, Iracema Fonseca de Albuquerque; FERREIRA, Nelson Jesus; SILVA, Maria Gertrudes Alvarez Justi da; SILVA DIAS, Maria Assunção Faus da (Ed.). Tempo e Clima no Brasil. São Paulo: Oficina de Textos, 2009. 463 p.

CCGE. Desertificação, degradação da terra e secas no Brasil. Centro de Gestão e Estudos Estratégicos Brasília. Brasília 2016. 252p. Disponível em: <https://www.cgee.org.br/documents/10195/734063/DesertificacaoWeb.pdf> [Consulta: 05 de agosto de 2020].

CEARÁ. Programa de Ação Estadual de Combate à Desertificação e Mitigação dos Efeitos da Seca, PAE - CE. Brasil: Edições Ministério do Meio Ambiente / Secretaria dos Recursos Hídricos, 2010. 372p. Disponível em: <http://www.mpce.mp.br/wpcontent/uploads/2016/05/PROGRAMA-ESTADUAL-DE-COMBATE-A-

DESERTIFICA\%C3\%87\%C3\%83O.pdf> [Consulta: 02 de agosto de 2020].

COSTA, Luis Ricardo Fernandes da; MAIA, Rubson Pinheiro; BARRETO, Lucas Lopes; SALES, Vanda Carneiro de Claudino. Geomorfologia do nordeste setentrional brasileiro: Uma proposta de classificação. Revista Brasileira de Geomorfologia. v. 21, $\mathrm{n}^{\circ}$ 1, 2020. 24p. Disponível em: <http://www.lsie.unb.br/rbg/index.php/rbg/article/view/1447> [Consulta: 10 de outubro de 2020].

COGERH. Companhia de Gestão dos Recursos Hídricos - Base cartográfica (mapas) / Versão, 2019. Disponível em: <https://www.cogerh.com.br/base-cartografica.html> [Consulta: $22 \mathrm{de}$ setembro de 2019].

CPRM. Companhia de Pesquisa de Recursos Minerais - Mapa Geológico do Estado do Ceará. 2003. Disponível em: <http://rigeo.cprm.gov.br/jspui/handle/doc/2355> [Consulta: 21 de setembro de 2019]. 
EMBRAPA. Empresa Brasileira de Pesquisa Agropecuária. Levantamento Exploratório / Reconhecimento de solos do Estado do Ceará - Escala 1: 600.000. 1973. Disponível em: <http://www.uep.cnps.embrapa.br/solos/index.php?link=ce> [Consulta: 22 de setembro de 2019].

ESPAÑA. Programa de Acción Nacional Contra la Desertificación. Ministerio de Medio Ambiente y Medio Rural y Marino, Gobierno de España. Agosto de 2008. 262p. Disponível em: $<$ https://www.mapa.gob.es/es/desarrollo-rural/temas/politicaforestal/pand_agosto_2008_tcm30-177181.pdf> [Consulta: 18 de julho de 2020].

FUNCEME. Compartimentação Geoambiental do Estado do Ceará. Fortaleza: Edições da Fundação Cearense de Meteorologia e Recursos Hídricos, 2009. 37p.

IBGE. Instituto Brasileiro de Geografia e Estatística - Mapeamento da vegetação do Brasil, versão 2019. Disponível em: <https://www.ibge.gov.br/geociencias/downloadsgeociencias.html> [Consulta: 22 de setembro de 2019].

INMET. Instituo Nacional de Meteorologia - Normais Climatológicas. Disponível em: <https://mapas.inmet.gov.br/> [Consulta em: 24 de setembro de 2020].

MAIA, Rubson Pinheiro; BEZERRA, Francisco Hilário Rêgo. Tópicos de geomorfologia estrutural: nordeste brasileiro. Fortaleza: Edições UFC, 2014. 124p.

PORTO, Kátia C; CABRAL, Jaime J. P.; TABARELLI, Marcelo. Brejos e altitude em Pernambuco e Paraíba: história natural, ecologia e conservação. Brasília: Ministério do Meio Ambiente, 2004. 324p.

SOUZA, Marcos José Nogueira de. Bases naturais e esboço do zoneamento geoambiental do Estado do Ceará. LIMA, Luiz Cruz, SOUZA; Marcos José Nogueira de; MORAIS, Jáder Onofre. Compartimentação Territorial e Gestão Regional do Ceará. Fortaleza: Ed. FUNECE, 6-98p, 2000.

VASCONCELOS SOBRINHO, João. O Deserto Brasileiro: projeto do trópico árido. Recife: UFRPE, 1974. 24p.

ZANELLA, M. E. As características climáticas e os recursos hídricos do Ceará. SILVA, José Borzacchiello da; CAVALCANTE, Tércia Correia; DANTAS, Eustógio Wanderley Correia. CEARÁ: um novo olhar geográfico. Fortaleza: Edições Demócrito Rocha, 169-188p, 2007.

(c) Copyright: Pedro Ítalo Carvalho Alderaldo, 2020.

(C) Copyright: Ar@cne, 2020.

Ficha bibliográfica:

ALDERADO, Pedro Ítalo Carvalho. Paisagens no núcleo de desertificação dos Inhamuns e seu entorno, Ceará, Brasil. Ar@cne. Revista Electrónica de Recursos de Internet sobre Geografia y Ciencias Sociales. Barcelona: Universidad de Barcelona, I de diciembre de 2020, vol. XXIV, n 249.

DOI: https://doi.org/I0.I344/ara2020.249.32906

\section{Menú Geo Crítica}

